\title{
Selective Adsorption of Nitrate and Nitrite from Tobacco Leaf Homogenates *
}

\author{
by
}

Patsy R. Rhodes

Department of Agronomy, University of Maryland, College Park, Maryland, U.S. A.

and

James A. Saunders

Tobacco Laboratory, Beltsville Agricultural Research Center, U.S. Department of Agriculture, Agricultural Research Service, Beltsville, Maryland, U.S.A.

\section{INTRODUCTION}

Nitrate and nitrite occur naturally in the environment in both plant and animal tissues. Even when present at high concentrations, nitrate has a very low toxicity (1); however, the reduction of nitrate to nitrite poses a significant health risk. Nitrite indirectly has the potential to react with secondary or tertiary amines forming $N$-nitroso compounds with carcinogenic, mutagenic, and toxic properties (2). The amount of nitrate in the tobacco leaf has been shown to be correlated with the levels of volatile $N$-nitrosamines in cigarette smoke (3). These volatile $N$-nitrosamines, which are considered to be organ-specific carcinogens, may be reduced in mainstream smoke through the use of cigarette filters. Cigarette filters, however, would have no beneficial effect on sidestream smoke or unfiltered smoking products, which expose both smokers and non-smokers to potentially hazardous levels of volatile $N$-nitrosamines. This investigation was undertaken to develop an effective means of reducing both nitrates and nitrites in tobacco smoke. For this purpose a nitrate/nitrite adsorbing polymer, poly(vinylbenzyl-nitron chloride) [PVB-nitron], was bound to several inert matrices so that this adsorbant could be regenerated for both laboratory and large scale operations. The relevant physicochemical adsorptive properties of PVB-nitron are described in relation to the reduction of nitrate in tobacco during the homogenized leaf curing process.

\footnotetext{
* Presented, in part, as the 35th 'Tobacco Chemists' Research Conference, Wirston-Szlem, N.C., in 1981.

Received; 8th February 1982 - accepted: 18th October 1982,

This work was supported by the U.S. Department of Agriculture, SEA, ARS Tobacos Laboratory, Beltsvilie, Md., and the Agronomy Department, University of Maryland, College Park, Md., Contribution No. 6156 under Cooperative Agreement No. 58-32U4-9-73-A01.
}

\section{MATERIALS AND METHODS}

\section{Plant Material}

Field-grown tobacco plants, Nicotiana tabacum MD 872 and NC 2326, were harvested one week after topping. Whole leaves, including the midrib, from the top, middle, and lower portions of each plant were homogenized at room temperature with an equivalent weight of $20 \mathrm{mM}$ sodium metabisulfite at $10^{\circ} \mathrm{C}$ to retard phenolic oxidation. The slurry was then passed through a press to express the soluble portions of the homogenate. This green filtrate was used for all subsequent nitrate and nitrite determinations in which both the $\mathrm{pH}$ and the temperature of the extract were varied. Prior to nitrate determinations, an equal volume of extracting solution supplied by Orion Research Inc. ${ }^{+}$, composed of $26 \mathrm{mM}$ aluminum sulfate, $21 \mathrm{mM}$ boric acid, $11 \mathrm{mM}$ silver sulfate, and $26 \mathrm{mM}$ sulfamic acid (adjusted to $\mathrm{pH} 3$ with $\mathrm{NaOH}$ ) was added to aliquots of the plant homogenates to remove endogenous substances which may interfere with the nitrate sensitive electrode (4). This $1: 1$ ratio of tobacco homogenate to extracting solution was sufficient to obtain a stable electrode response.

\section{Determination of Nitrate and Nitrite Concentrations}

Nitrate and nitrite ions were routinely measured with an Orion Model $811 \mathrm{pH}$ meter equipped with an Orion nitrate sensitive electrode. Standard curves were linear in the range of $0.1 \mathrm{mM}$ to $100 \mathrm{mM}$ for $\mathrm{KNO}_{3}$ and $1 \mathrm{mM}$ to. $100 \mathrm{mM}$ for $\mathrm{KNO}_{2}$. The addition of potassium ni-

\footnotetext{
+ Mention of a trade name or proprietary product does not constitute a guaranzee or warranty of the product by the United Scaces Department of Agriculture and does not imply jts approval to the exclusion of orher produces that may also be suitable.
} 
trate/nitrite standards to mixtures of both the tobacco homogenates and Orion extracting solution also produced the expected linear electrode responses. The use of the Orion extracting solution was necessary to eliminate electrode interference from endogenous ions which may be present in tobacco leaf tissues.

The ion electrode cannot selectively distinguish between nitrate and nitrite in plant tissues. To determine what fraction of the electrode reading was attributable to nitrate, a colorimetric assay was used to measure the amount of nitrite in tobacco leaves. For this assay it was first necessary to decolorize the green plant extract. Chlorophyll was removed using a two-phase extraction procedure with methylene chloride described by Klepper (5). This procedure consisted of a 1:1 extraction with methylene chloride until the aqueous phase was amber in color. Subsequently, nitrite in the aqueous phase was determined by diazotization with a sulfanilic acid: $N$-(1-naphthyl)ethylenediamine dihydrochloride reagent $(6,7)$. The $A_{540}$ of the resulting color reaction was measured and compared with a standard curve of potassium nitrite in the range of $0.1 \mu \mathrm{M}$ to $100 \mathrm{mM}$.

\section{Preparation of the Nitrate-Nitrite Selective Polymer}

Nitron (Eastman Chemical Company) was treated with poly(vinylbenzyl chloride) $60 / 40$ ortho/para isomers

Flgure 1. Chemlcal structure of the nitrate/nitrite selective reagent, the polymer backbone, and their reaction product.

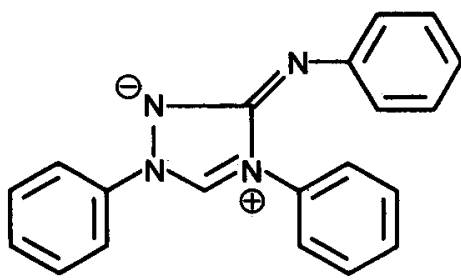

Nitron

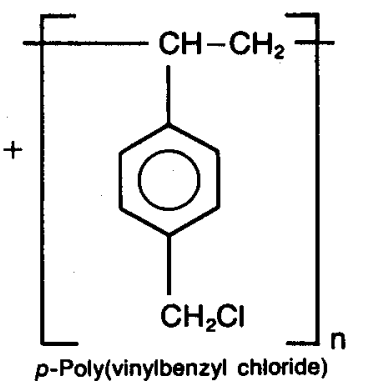

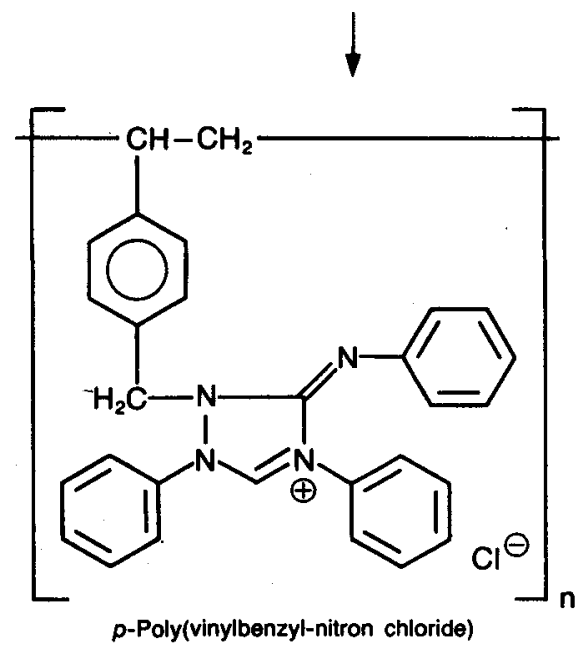

(Aldrich Chemical Company) to produce the polymer, PVB-nitron. The structures of these compounds and the reaction product are illustrated in Figure 1. Based on the protocol of Chiou (8) and Chion et al. (9), a typical preparation would consist of $25 \mathrm{ml}$ of $0.6 \mathrm{M}$ nitron in $N, N$-dimethylformamide stirred into $20 \mathrm{ml}$ of $0.5 \mathrm{M}$ poly(vinylbenzyl chloride) dissolved in the same solvent. Nitron was then treated with the poly(vinylbenzyl chloride) by refluxing this mixture under $\mathrm{N}_{2}$ at $140^{\circ} \mathrm{C}$ for $48 \mathrm{~h}$. The $\mathrm{N}_{2}$ gas was bubbled through the tip of a pasteur pipet so that the mixture was continuously agitated.

To facilitate recovery of the nitrate adsorbing polymer from aqueous leaf extracts, the PVB-nitron was adsorbed onto the surface of several inert supports. These included Sephadex G-25 (coarse), glass beads, diatomaceous earth, and acid-washed sand. The adsorption of PVB-nitron onto these solid supports was accomplished by two methods.

Method I: Untreated nitron was separated from PVBnitron by precipitation of the polymer in four volumes of acetone. This precipitate was collected by filtration in a büchner funnel and residual traces of nitron were removed by six successive washes with equal volumes of acetone. The dry solid which remained was approximately $50 \%$ of the total weight of nitron and poly(vinylbenzyl chloride) used. This reaction product was then redissolved in dimethylformamide (1 gram product $/ 25 \mathrm{ml}$ solvent), mixed with the inert support material, and stirred to dryness in a fume hood under a stream of air. Solvent evaporation could be accomplished through use of a Buchler rotary evaporator when small amounts of polymer were needed but this system proved too cumbersome for the production of large quantities of PVBnitron-coated support materials.

The reactive capacity of PVB-nitron prepared in this way was expressed in terms of moles of nitron present in the inert supporting material. This could be determined by weighing the dry support before and after the addition of the PVB-nitron polymer. The change in weight was attributed to the quantity of polymer bound to the support as all unbound PVB-nitron was removed by the washing procedures.

Method II: Dimethylformamide, which is used as a solvent in the procedure outlined above, has been reported to have embryotoxic properties when pregnant laboratory rats are subjected to high doses of this solvent (10). In an effort to reduce the amount of dimethylformamide used as a solvent, a slight modification of the procedure used in Method I was developed. Rather than precipitating the polymer with acetone, the reaction mixture was poured directly onto the inert support material and the mixture stirred until the solvent evaporated. The unpolymerized nitron was removed by extensive distilled water rinses, thus the reactive capacity of PVB-nitron prepared by Method II was based upon the moles of nitron present in the reaction mixture whether bound to the polymer or not. 
Use and Regeneration of Poly(vinylbenzyl-nitron chloride)

The tobacco leaf homogenates as well as the nitrate/nitrite standards were routinely exposed to PVB-nitron linked to the inert medium by stirring the sample in a beaker with the solid support for 30 minutes. The supernatant was then decanted leaving the PVB-nitron and support medium behind. Alternatively, homogenates were exposed to the nitrate adsorbent by passing the leaf extract through a column $(2 \mathrm{~cm} \times 20 \mathrm{~cm})$ of the PVB-nitron-coated support medium. Samples were always adjusted to room temperature before nitrate or nitrite levels were determined.

In order to regenerate and reuse the adsorbent following exposure to aqueous nitrate or nitrite solutions, the PVB-nitron-coated support was first thoroughly rinsed with water and drained. Bound nitrate and nitrite were then exchanged for chloride ions by stirring the PVBnitron support with five volumes of $0.1 \mathrm{M}$ ammonium chloride. Regeneration of the PVB-nitron-support was completed by rinsing with four volumes of distilled water.

\section{RESULTS AND DISCUSSION}

In tobacco, nitrate appears to be a precursor of the organ specific carcinogens, the volatile $N$-nitrosamines (3). In this study we have used the homogenized leaf curing process to demonstrate the utility of a convenient technique to reduce endogenous nitrate and nitrite in green tobacco. An important feature of this procedure for the extraction of nitrate from plant tissues is the ability to recover and regenerate the anion-binding adsorbant. For this purpose, the PVB-nitron was linked to several inert supports including sand, Sephadex, acid-washed diatomaceous earth and glass beads. The PVB-nitron adhered to the surfaces of the sand, Sephadex, and acid-washed diatomaceous earth but not to the glass beads to form a stable complex in aqueous solutions. Of the several support materials tested, sand proved well suited for use when leaf extracts were either stirred with the bound adsorbant or were passed through columns containing the PVB-nitron support. The adsorbent properties of PVB-nitron described in this report, therefore, are primarily those of PVB-nitron-coated sand.

The sand grains, with an average particle diameter of 300 micrometers and an irregular surface, provided a large area for binding PVB-nitron. If PVB-nitron were to coat the entire surface of the sand grain in a monolayer, the maximum number of anion-binding sites per unit of sand would be exposed. In practice, however, multiple layers of PVB-nitron can be expected to form; under these conditions, only the outermost coating of PVB-nitron would be able to adsorb nitrate and nitrite. To estimate the maximum amount of PVB-nitron which could be applied to the surface of sand, the sand was saturated with PVB-nitron as shown in Table 1. The maximum anion-binding capacity of the PVB-nitroncoated sand was approached with the application of $10 \mathrm{~g}$ of Method I PVB-nitron per $100 \mathrm{~g}$ sand and the amount of anion adsorbed was proportional but not linear to the amount of PVB-nitron applied. This deviation from linearity was attributed to multiple layers of nitron which masked anion-binding sites.

Some masking of PVB-nitron-binding sites was evident even at the lowest levels of adsorbant applied to the sand surface by either Method I or II. When the PVBnitron was adsorbed directly onto the surface of the support by the techniques used in Method II, surface saturation of the support was not achieved as it was when Method I was used. This was attributed to excess unpolymerized nitron, which was removed from the support by extensive washes in distilled water. Five

Table 1. Capacity of sand for adsorption of PVB-nitron.

\begin{tabular}{|c|c|c|c|c|}
\hline \multirow{2}{*}{$\begin{array}{l}\text { PVB-nitron } \\
\text { concentration } \\
\text { per } 100 \mathrm{~g} \text { sand }\end{array}$} & \multicolumn{2}{|c|}{ Nitrate* } & \multicolumn{2}{|c|}{ Nitrite** } \\
\hline & $\begin{array}{l}\text { mmoles adsorbed } \\
\text { per } 100 \mathrm{~g} \text { sand }\end{array}$ & $\begin{array}{l}\text { percentage } \\
\text { efficiency }^{+}\end{array}$ & $\begin{array}{l}\text { mmoles adsorbed } \\
\text { per } 100 \mathrm{~g} \text { sand }\end{array}$ & $\begin{array}{l}\text { percentage } \\
\text { efficiency }^{+}\end{array}$ \\
\hline \multicolumn{5}{|l|}{ Method I } \\
\hline $1.00 \mathrm{~g}$ & 0.64 & 32 & 1.14 & 57 \\
\hline $5.00 \mathrm{~g}$ & 1.54 & 77 & 1.76 & 88 \\
\hline $10.00 \mathrm{~g}$ & 1.90 & 95 & 1.92 & 96 \\
\hline $15.00 \mathrm{~g}$ & 1.96 & 98 & 1.94 & 97 \\
\hline \multicolumn{5}{|l|}{ Method II } \\
\hline $1 \mathrm{mmol}$ & 0.52 & 26 & 0.40 & 20 \\
\hline $5 \mathrm{mmol}$ & 0.96 & 48 & 1.30 & 65 \\
\hline $10 \mathrm{mmol}$ & 1.32 & 66 & 1.54 & 77 \\
\hline $15 \mathrm{mmol}$ & 1.50 & 75 & 1.62 & 81 \\
\hline
\end{tabular}

\footnotetext{
- With an initial concentration of $10 \mathrm{mM} \mathrm{KNO}$.

** With an initial concentration of $10 \mathrm{mM} \mathrm{KNO}_{2}$.

+ Percentage etficiency $=$ (moles anion adsorbed $/$ moles anion applied) $\times 100$.
} 
Table 2. Nitrate and nitrite adsorption efflclency of PVB-nitron-coated sand *.

\begin{tabular}{c|c|c|c|c}
\hline \multirow{2}{*}{$\begin{array}{l}\text { Initial anion } \\
\text { concentration (mM) }\end{array}$} & \multicolumn{2}{|c}{ Nitrate } & \multicolumn{2}{c}{ Nitrite } \\
\cline { 2 - 5 } & $\begin{array}{c}\text { mmoles adsorbed } \\
\text { per 100 g sand }\end{array}$ & $\begin{array}{c}\text { 作 } \\
\text { percentage } \\
\text { efficiency }\end{array}$ & $\begin{array}{c}\text { mmoles adsorbed } \\
\text { per 100 g sand }\end{array}$ & $\begin{array}{c}\text { percentage } \\
\text { efficiency }\end{array}$ \\
\hline 100 & 1.600 & 8 & 3.000 & 15 \\
25 & 0.800 & 16 & 1.420 & 28 \\
10 & 0.480 & 24 & 1.200 & 60 \\
6.2 & 0.560 & 45 & 0.860 & 70 \\
1.55 & 0.202 & 65 & 0.270 & 88 \\
1.0 & 0.145 & 72 & 0.160 & 82 \\
\hline
\end{tabular}

* Prepared by Method I: $0.233 \mathrm{~g}$ PVB-nitron per $100 \mathrm{~g}$ sand.

** Percentage efficiency $=$ (moles anion adsobed $/$ moles anion applied) $\times 100$.

Table 3. Nitrate and nitrite binding capaclty of PVB-nitron-coated sand.

\begin{tabular}{|c|c|c|c|c|}
\hline \multirow{2}{*}{$\begin{array}{l}\text { PVB-nitron } \\
\text { concentration } \\
\text { per } 100 \mathrm{~g} \text { sand }\end{array}$} & \multicolumn{2}{|c|}{ Nitrate* } & \multicolumn{2}{|c|}{ Nitrite** } \\
\hline & $\begin{array}{l}\text { mmoles applied } \\
\text { per } 100 \mathrm{~g} \text { sand }\end{array}$ & $\begin{array}{l}\text { mmoles adsorbed } \\
\text { per } 100 \mathrm{~g} \text { sand }\end{array}$ & $\begin{array}{l}\text { mmoles applied } \\
\text { per } 100 \mathrm{~g} \text { sand }\end{array}$ & $\begin{array}{l}\text { mmoles adsorbed } \\
\text { per } 100 \mathrm{~g} \text { sand }\end{array}$ \\
\hline \multicolumn{5}{|l|}{ Method I } \\
\hline $0.23 \mathrm{~g}$ & 0.16 & 0.10 & 10.0 & 3.00 \\
\hline $1.16 \mathrm{~g}$ & 0.65 & 0.40 & 12.5 & 3.42 \\
\hline \multicolumn{5}{|l|}{ Method II } \\
\hline $1 \mathrm{mmol}$ & 0.25 & 0.11 & 10.0 & 2.90 \\
\hline $2 \mathrm{mmol}$ & 0.38 & 0.24 & 10.0 & 4.37 \\
\hline $4 \mathrm{mmol}$ & 0.55 & 0.44 & 12.5 & 5.17 \\
\hline
\end{tabular}

* With an initial concentration of $1 \mathrm{mM} \mathrm{KNO}$

** With an initial concentration of $100 \mathrm{mM} \mathrm{KNO}_{2}$

Table 4. Efficlency of nitrate removal from homogenized tobacco leaves with varled reaction conditions.

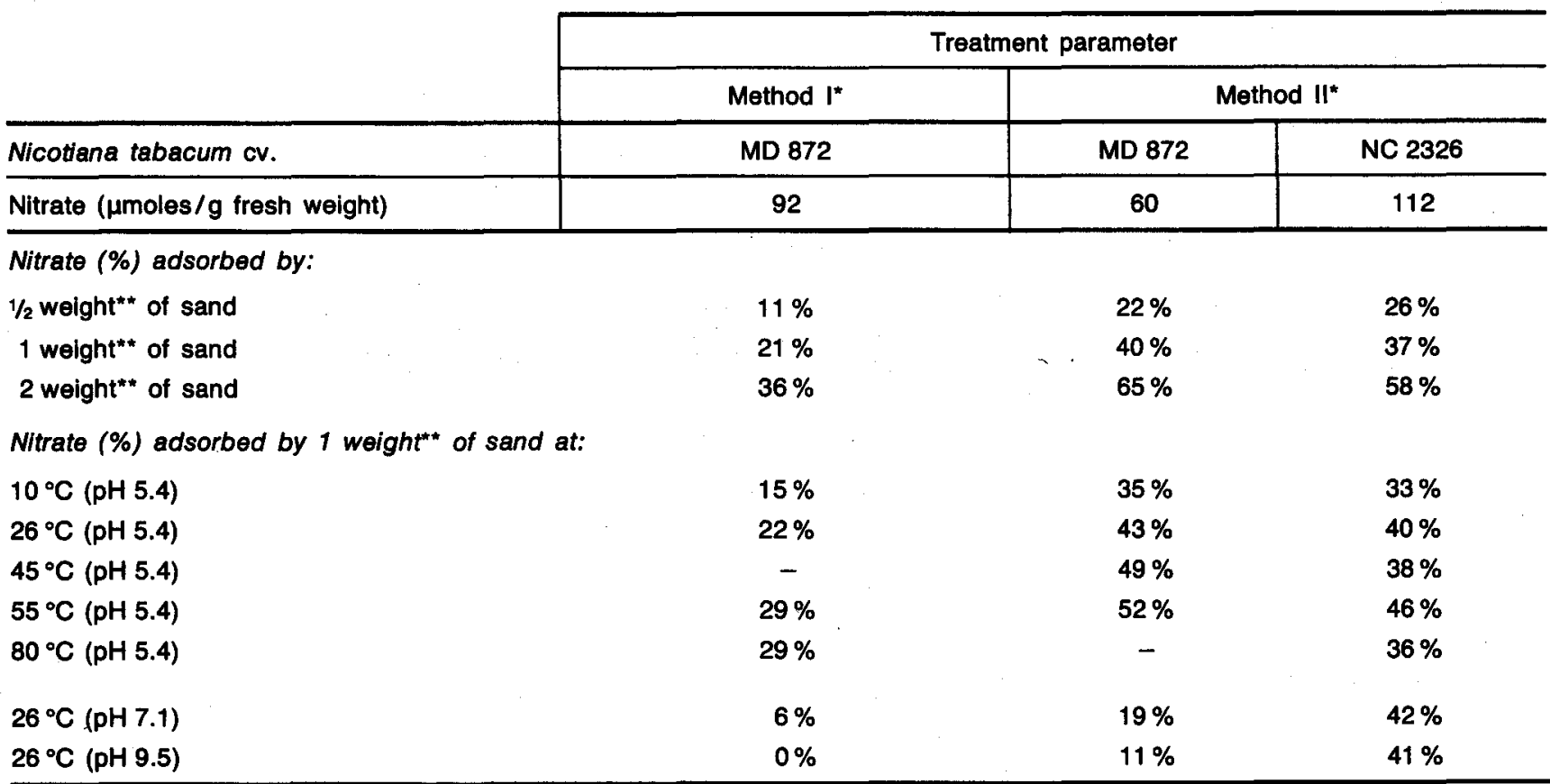

\footnotetext{
- In Method I, $2.2 \mathrm{~kg}$ of plant tissue was utilized. The sand was prepared with a ratio of $0.427 \mathrm{~g}$ of PVB-nitron per $100 \mathrm{~g}$ sand. In Method II, $136 \mathrm{~kg}$ of plant material was used. In this case a ratio of 2.36 mmoles nitron per $100 \mathrm{~g}$ sand was used and the sand used with MD 872 was regenerated for use with NC 2326.

** For Method I: 1 weight of sand $=100 \mathrm{~g}$. For Method II: 1 weight of sand $=4540 \mathrm{~g}$.
} 
mmoles of PVB-nitron prepared by the procedure of Method II would normally yield $1 \mathrm{~g}$ of PVB-nitron if processed by Method I. Consequently, the concentration of PVB-nitron per $100 \mathrm{~g}$ of sand prepared by Method II was considerably less than that achieved with Method I. When this differential accumulation of PVBnitron was taken into account, the adsorptive capacity of 5 mmoles of PVB-nitron prepared by Method II agreed quite well with the adsorptive capacity of $1 \mathrm{~g}$ of PVB-nitron prepared by Method I.

As is evident from the data presented in Table 1, the total quantity of nitrate and nitrite adsorbed was dependent upon the amount of PVB-nitron which was coated onto the sand surface. If the concentration of PVB-nitron was kept constant, then the amount of nitrate and nitrite adsorbed also was dependent upon the anion concentration. The data in Table 2 demonstrate that the amount of both nitrate and nitrite adsorbed increased sharply as the anion concentration was raised. The equilibrium established between adsorbed and non-adsorbed anions approached a limiting saturation value at high concentrations of nitrate and nitrite where proportionately more anions remained in solution than were adsorbed by the PVB-nitron-coated sand. This is apparent in the nitrate and nitrite adsorption efficiencies presented in Table 2. The relationships between anion concentration $(x)$ and the amount of adsorbed anion (y) are described by the following adsorption isotherms: $y=0.16 x^{0.51}$ and $y=0.21 x^{0.62}$ for nitrate and nitrite, respectively. The constants, 0.16 and 0.21 , represent the fraction of the anions which can be adsorbed (that is the saturation value when $\dot{x}=1$ ). The ability of PVB-nitron to adsorb nitrite with a greater affinity than nitrate is also evident in the data presented in Tables 1 and 3.

Saturation of the PVB-nitron system was also examined by the gradual addition of nitrate and nitrite to PVBnitron-coated sand in Figure 2. For this purpose, the sample was allowed to drain through a $2 \mathrm{~cm} \times 20 \mathrm{~cm}$ vertical column loaded with PVB-nitron-coated sand. The first aliquots introduced in this manner were completely adsorbed by PVB-nitron; but as the saturation level of the PVB-nitron was approached, a greater proportion of the nitrate and nitrite in each aliquot remained unbound until the amount of anions taken up by PVB-nitron was negligible. The total amounts of nitrate and nitrite adsorbed in this manner at various anion and PVB-nitron concentrations are presented in Table 3. These values for anion capacity agree quite well with those reported in Tables 1 and 2 where stirred anion solutions were employed and indicate that stirring was at least as efficient at removing anions as percolation through a column of adsorbent material.

The data in Table 3 show a linear increase of nitratebinding capacity in relation to increasing PVB-nitron concentrations applied to sand. These data suggest that a single layer of PVB-nitron with maximum exposure of the anion-binding sites can be obtained if less than $1 \mathrm{~g}$ of Method I or less than 5 mmoles of Method II PVBnitron are used per $100 \mathrm{~g}$ sand.

Using aqueous extracts from homogenized tobacco leaf
Figure 2. Nitrate saturation of 1 mmole [a], 2 mmoles [b], or 4 mmoles [c] of PVB-nitron attached to $100 \mathrm{~g}$ of sand by Method II. A solution of $1 \mathrm{mM} \mathrm{KNO}{ }_{3}$ was allowed to drain through the sand in $25 \mathrm{ml}$ aliquots until the electrode potential of the effluent approached that of the stock solution.

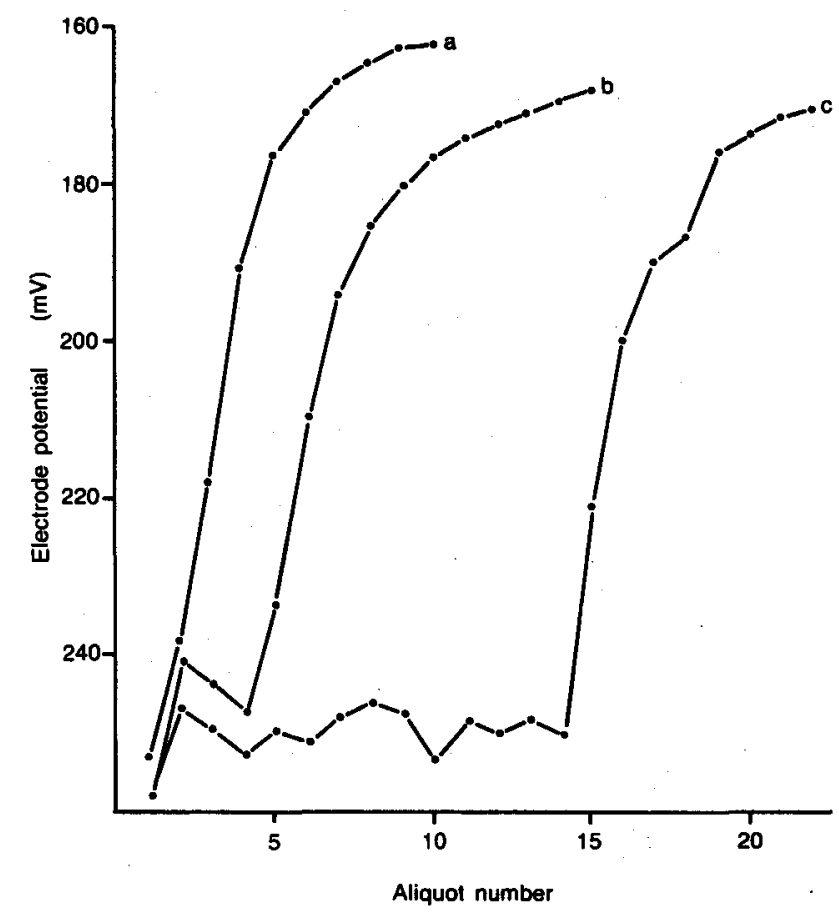

tissue, the data in Table 4 show that the concentration of nitrate in tobacco leaves was within the linear range of the adsorptive capacity of the PVB-nitron-coated sand. The leaf extracts had concentrations of nitrate ranging from $40 \mathrm{mM}$ to $60 \mathrm{mM}$, while the level of nitrite in this tissue was below our detectable limits. Using the Method I procedure for preparing PVB-nitron with the tobacco variety $M D 872$, a total of 11.8 mmoles of nitrate present in the homogenate was applied per $100 \mathrm{~g}$ of sand. For the data in Table 4 using MD 872 and NC 2326, a total of 420 and 915 mmoles of nitrate were added per $100 \mathrm{~g}$ of sand to the PVB-nitron prepared by Method II. The amount of nitrate adsorbed from each of the tobacco leaf extracts was proportional to the anion concentration following the results obtained in Table 2. As expected for a single layer of PVB-nitron, the amount of nitrate adsorbed from these leaf homogenates was also proportional to the weight of PVB-nitron-coated sand.

The effect of temperature and $\mathrm{pH}$ on the nitrate-binding capacity of PVB-nitron was also examined using MD 872 and NC 2326 tobacco (Table 4). Exposure of tobacco leaf extracts to PVB-nitron over a 10 to $55^{\circ} \mathrm{C}$ range showed a general enhancement in the adsorption of nitrate. Above $55^{\circ} \mathrm{C}$ no additional enhancement of nitrate binding was observed. Using MD 872 tobacco, an increase in the $\mathrm{pH}$ of the processing mixture resulted in a reduction of the amount of nitrate adsorbed.

An important aspect in the removal of nitrate and nitrite from plant material by PVB-nitron concerns the regeneration process. For these purposes, the exchange of 
chloride for nitrate or nitrite anions may be accomplished with chloride salts of sodium, ammonium, magnesium, or potassium. The selection of ammonium chloride results in an effluent containing ammonium nitrate which may have potential use as organic nitrate fertilizer.

The PVB-nitron-coated sand was regenerated after processing the MD 872 samples and the same material was used for the NC 2326 leaf tissue. The regeneration and recovery of the adsorptive PVB-nitron without a reduction of nitrate-binding ability is shown in Table 4. PVBnitron has been reported to be regenerated as many as 25 times under controlled conditions with no detectable loss of nitrate-adsorbing capacity (8).

This study has shown that nitrate and nitrite can be effectively removed from homogenates of tobacco leaf material and that the system can be transferred successfully from the laboratory to a small pilot plant operation. Several important aspects of the adsorption of anions by the PVB-nitron complex bear strongly upon the usefulness of this procedure and should be mentioned. In addition to its affinity for nitrate and nitrite, nitron has also been reported to have a small adsorptive affinity for certain other anions including $\mathrm{SCN}^{-}$, $\mathrm{ClO}_{4}^{-}, \mathrm{I}^{-}, \mathrm{ClO}_{3}^{-}, \mathrm{CrO}_{4}{ }^{2-}$, and $\mathrm{Br}^{-}$(11). Given the strong preference of nitron for nitrate and nitrite, this attraction for other anions would not usually have a significant role in the adsorptive process. In some leaf tissues, however, a number of these anions may contribute to the toxicity of the plant material (12). The potential for nitron to reduce the level of the accessory anions in these cases would also be a significant justification for the use of this procedure.

A final aspect of the nitrate removal process described herein involves its general application to the reduction of nitrate and nitrite in tissues other than tobacco leaf homogenates. A wide variety of plants (barley, sorghum, sugar-beets, Johnson grass, and pigweed) have been known to accumulate potentially toxic levels of nitrate in vegetative tissues (12). The nitrate content of these leaf tissues from the economic crops can often be controlled with careful fertilization practices that limit soil nitrogen. In both agronomic crops and common field plants, however, a host of environmental factors which are difficult to adequately control, such as drought, sudden reductions in temperature, and reduced sunlight, also influence nitrate accumulation in vegetative tissues (13). Adaptation of the nitrate adsorptive process described in this study to commercially processed animal fodder could make use of marginal forage crops without risk to livestock of potentially toxic forage (14).

\section{SUMMARY}

A procedure has been developed for the reduction of nitrate/nitrite in tobacco during the homogenized leaf curing process. This procedure involves the precipitation of these anions with a polymer composed of the nitron 1,4-diphenyl-3,5-endo-anilino-4,5-dihydro-1,2,4-triazole linked to poly(vinylbenzyl chloride). This poly(vinylbenzyl-nitron chloride) complex was coated onto several inert supporting materials and tested for anion binding capacity using nitrate/nitrite standards and tobacco leaf extracts. When coated onto the surface of acid-washed sand, the nitron polymer was capable of repeated regeneration with no detectable loss of nitrate/ nitrite binding capacity. The nitron polymer had a slightly greater affinity for nitrite than for nitrate; however, due to the high ratio of nitrate to nitrite in tobacco leaf tissues, nitrate was the principle anion adsorbed from leaf homogenates. Large scale application of this selective nitrate adsorbing polymer during homogenized leaf curing of tobacco could significantly reduce these potentially harmful components in smoking products.

\section{ZUSAMMENFASSUNG}

Zur Reduzierung des Nitrat/Nitrit-Gehaltes im Tabak während des Trocknungsprozesses mit der HLC-Methode (homogenized leaf curing) wurde ein Verfahren entwickelt, das auf der Fällung dieser Anionen mit einem aus dem Nitron 1,4-Diphenyl-3,5-endo-anilino4,5-dihydro-1,2,4-triazol und daran gebundenem Polyvinylbenzylchlorid bestehenden Polymerisat basiert. Durch Beschichtung mehrerer inerter Trägerstoffe mit diesem Polyvinylbenzyl-nitron-Komplex wurde unter Einsatz von Nitrat/Nitrit-Standards und Tabakblattextrakten geprüft, inwieweit diese Verbindung fähig ist, die Anionen zu binden. Wenn die Oberfläche von mit Säure behandeltem Sand mit dem Nitronpolymer überzogen wurde, war das Polymer mehrmals regenerierbar, ohne daß eine Verminderung der Bindungsfähigkeit für Nitrat/Nitrit erkennbar wurde. Das Nitronpolymer zeigte eine etwas größere Affinität zu Nitrit als zu Nitrat. Aufgrund des hohen Wertes für das Nitrat/NitritVerhältnis im Blattgewebe von Tabak war es jedoch vor allem das Nitrat, das aus dem Blatthomogenat adsorbiert wurde. Durch Anwendung dieser selektiven Nitratadsorption in großem Maßstab während des HLCTrocknungsprozesses wäre es möglich, diese potentiell schädlichen Bestandteile der Rauchprodukte erheblich $\mathrm{zu}$ vermindern.

\section{RÉSUMÉ}

Un système de réduction de la teneur en nitrate/nitrite du tabac durant le séchage selon la méthode HLC (homogenized leaf curing) a été mis au point. Celui-ci repose sur la précipitation de ces anions à l'aide d'un polymère composé de nitron 1,4-diphényl-3,5-endoanilino-4,5-dihydro-1,2,4-triazol et de chlorure de polyvinyle benzyle. On a enduit plusieurs supports inertes de ce complexe de nitron et polyvinyle benzyle et vérifié, à l'aide de composés-types nitrate/nitrite et d'extraits de feuilles de tabac, dans quelle mesure il était possible de lier les anions. Lorsque le polymère de ni- 
tron a été déposé à la surface d'un sable traité à l'acide, il est en mesure de se régénérer plusieurs fois, sans que l'on puisse vraiment déceler une diminution de son pouvoir de liaison du nitrate/nitrite. Le polymère de nitron a certes une affinité un peu plus prononcée pour le nitrite que pour le nitrate, mais vu le plus grand rapport nitrate/nitrite contenu dans le tissu des feuilles de tabac, c'est cependant le nitrate qui est adsorbé en plus grande quantité. Une utilisation à plus grande échelle de ce procédé d'adsorption sélective du nitrate durant le processus de séchage HLC, permettrait de réduire considérablement ces composants potentiellement nuisibles dans les produits à fumer.

\section{REFERENCES}

1. Lewis, Richard J., and Rodger L. Tatken (eds.): Registry of toxic effects of chemical substances, 1978 edition; U.S. Department of Health, Education and Welfare, Public Health Services, DHEW (NIOSH) Publication No. 79-100, U.S. Government Printing Office, Washington, D.C., 1979.

2. World Health Organization: Environmental health criteria, 5. Nitrates, nitrites, and $N$-nitroso compounds; Geneva, Switzerland, 1978, pp. 45-73.

3. Hoffmann, D., C. B. Chen and S. S. Hecht: The role of volatile and non-volatile $N$-nitrosamines in tobacco carcinogenesis; in: Banbury Report, Vol. 3: A safe cigarette, edited by G. B. Gori and Fred G. Bock, Cold Spring Harbor Laboratory, Cold Spring Harbor, N.Y., 1980, pp. 113-127.

4. Orion Electrode Methods Manual, Series 93: Nitrate extraction from plant tissues; Orion Research Incorporated, Cambridge, Mass., 1979.

5. Klepper, L. A.: An improved method for nitrite extraction from plants; J. Agric. Food Chern. 27 (1979) 438-441.

6. Klepper, L. A. (University of Nebraska at Lincoln, Nebraska): A mode of action of herbicides, Inhibition of the normal process of nitrite reduction; Nebr. Exp. Sta. Res. Bull 259, 1974.

7. Barker, A. W. (University of Massachusetts at Amherst, Mass.): Nitrate determinations in soil, water and plants; Mass. Exp. Sta. Res. Bull. 611, 1974.
8. Chiou, S. J.: The synthesis of nitrate and nitrite selective polymers; Ph.D. dissertation, Dept. of Chem., Kansas State University, Manhattan, Kansas, 1980.

9. Chiou, S. J., T. Geran, C. E. Meloan and W. C. Danen: A nitron-polyvinylbenzyl chloride polymer to selectively remove oxidizing anions from nonoxidizing anions - Removal of $\mathrm{NO}_{3}^{-}$and $\mathrm{NO}_{2}^{-}$ from polluted waters; Anal. Lett. 14 (1981) 865-871.

10. Dupont Chemical Company: DMF product use, storage and handling bulletin; supplied by Dupont Chemical Company Environmental Health and Safety Division, Wilmington, Delaware, p. 12, E-37563, 1980.

11. Feigl, F.: Chemistry of specific, selective and sensitive reactions; Academic Press, New York, N.Y., 1949, pp. 306-310.

12. Kingsbury, J. M.: Poisonous plants of the United States and Canada; Prentice-Hall, Englewood Cliffs, New Jersey, 1964, pp. 38-43.

13. Deeb, B., and K. W. Sloan (University of Illinois at Urbana-Champaign): Nitrates, nitrites and health; University of Illinois Agricultural Exp. Sta. Res. Bull. 750, 1975.

14. Kromann, R. P.; J. M. Weikel and L. F. Falen: Nitrate toxicity in dairy and beef cattle; Washington State University Bull. 821, 1976.

\section{Acknowledgments}

We wish to thank Dr. Denise Blume for the use of the pilot plant facilities at the U.S.D.A. Tobacco Experiment Station, Oxford, North Carolina, and Dr. Wayne C. Danen for bis valuable technical advice. We also wish to thank E. I. DuPont de Nemours and Company for the generous gift of $N, N$-dimetbylformamide.

Authors' address:

James A. Saunders, Tobacco Laboratory, Beltsville Agricultural Research Center, U.S. Department of Agriculture, Agricultural Research Service, Beltsville, Maryland, 20705, U.S.A. 